Jurnal Ilmu-Ilmu Peternakan 25 (2): 49 - 61

ISSN: 0852-3581

E-ISSN: 9772443D76DD3

CFakultas Peternakan UB, http://jiip.ub.ac.id/

\title{
Profil sistem integrasi usaha sapi perah dengan tanaman hortikultura di Nongkojajar Kecamatan Tutur Kabupaten Pasuruan
}

\author{
Richard E. M. F. Osak ${ }^{1}$, Budi Hartono ${ }^{2}$, Zainal Fanani ${ }^{2}$ dan Hari Dwi Utami ${ }^{2}$ \\ ${ }^{1}$ Fakultas Peternakan Universitas Sam Ratulangi, Kampus-Bahu, Manado \\ ${ }^{2}$ Fakultas Peternakan Universitas Brawijaya Malang \\ J1. Veteran Malang 65145 Jawa Timur \\ richard_osak@yahoo.com
}

\begin{abstract}
The study tended to evaluate dairy-horticulture integration system among dairy farmers as the member of the Koperasi Peternak Sapi Perah (KPSP) Setia Kawan in Nongkojajar, Pasuruan regency. The method of the study was survey and data were analyzed descriptively. The study found that the revenue earned from dairy cattle farming was IDR 23.357.321,17 $\pm 9.938 .351(46,54 \%)$, horticultural crops farming was IDR 10.030.225,41 $\pm 7.752 .962(19.99 \%)$, forage fodder was IDR 12.380.163,93 \pm 9.569 .370$ $(24.67 \%)$ and plant waste feed was IDR 1.595.665,57 $\pm 1.233 .386(3.18 \%)$ and the revenue derived from biogas and bioslurry in dairy-horticultural farming system was about

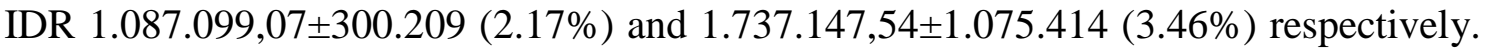
The average biogas production per year was found about $285.39 \pm 176.68 \mathrm{~kg}$ which was equal to LPG, but the farm household in the study area only used $100.80 \pm 27.84 \mathrm{~kg}$ per year.
\end{abstract}

Keywords: Profile, dairy, horticulture, integration, Nongkojajar

\section{PENDAHULUAN}

Pertanian yang berwawasan lingkungan dewasa ini menjadi tema kajian penelitian dan pertimbangan pengambilan kebijakan mengingat praktek pertanian konvensional selama ini dianggap kurang memberi perhatian terhadap aspek lingkungan. Pertanian konvensional masih banyak diterapkan di negara-negara sedang berkembang, berpenghasilan rendah dan menengah.

Pengembangan peternakan yang berwawasan lingkungan sudah seharusnya dilakukan melalui sistem peternakan terpadu dan berkelanjutan guna mereduksi efek terhadap kerusakan lingkungan yang ditimbulkan oleh ternak khususnya ternak ruminansia. Adiarto (2012) menjelaskan bahwa ternak ruminansia dapat menyebabkan kerusakan lingkungan mulai dari tingkat ringan hingga tingkat yang mengkhawatirkan, seperti pencemaran udara dan pencemaran air tanah.

Peternakan ruminansia seperti sapi, kambing dan domba dianggap menjadi salah satu penyumbang pemanasan global, namun Chuzaemi (2009) menjelaskan bahwa masyarakat Indonesia tidak perlu kuatir sebab hal itu bisa diatasi dengan cara membangun sistem peternakan terpadu.

Sistem pertanian terpadu (integrated farming system) antara ternak dengan tanaman telah menjadi salah 
satu program pemerintah dalam program pengembangan peternakan berwawasan lingkungan. Sujana (2009) menjelaskan bahwa sistem peternakan terpadu yaitu sistem terintegrasi ternak sapi dengan tanaman saat ini telah menjadi prioritas nasional untuk menciptakan lingkungan pertanian yang bersahabat.

$$
\text { Pada sistem integrasi, }
$$

pemanfaatan limbah peternakan berupa kotoran ternak (manure) diolah menjadi pupuk organik untuk tanaman baik tanaman hortikultura maupun tanaman hijauan makanan ternak. Pupuk organik merupakan salah satu alternatif yang sangat tepat untuk mengatasi kelangkaan dan naiknya harga pupuk, serta mereduksi penggunaan input pupuk kimia sebagai praktek pertanian berkelanjutan rendah input eksternal (low external input sustainable agriculture). Pada proses lebih lanjut kotoran ternak ini dibuat biogas sebagai substitusi bahan bakar yang makin mahal akibat pencabutan subsidi BBM, serta mereduksi efek gas rumah kaca (GRK). Keseluruhan proses dalam integrasi ternak dan tanaman bermuara pada peningkatan pendapatan petani peternak. FAO (2010) menegaskan untuk mempertahankan kualitas sumberdaya lingkungan pertanian peternakan sebagai bagian dari pengembangan pertanian peternakan berkelanjutan dan berwawasan lingkungan (environtmental friendly and sustainable development).

Salah satu usaha ternak yang perlu dikembangkan dengan usahatani berwawasan lingkungan yaitu usaha ternak sapi perah. Usahatani ternak sapi perah perlu diintegrasikan dengan tanaman, sebab banyak manfaat yang dihasilkan dari sistem integrasi tanaman ternak. Oleh karena itu, penelitian ini mengkaji profil sistem integrasi sapi perah dengan tanaman hortikultura
(SISpTA) pada peternak sapi perah anggota Koperasi Peternak Sapi Perah (KPSP) Setia Kawan di Nongkojajar Kecamatan Tutur Kabupaten Pasuruan.

\section{MATERI DAN METODE}

Penelitian ini dilakukan di Kecamatan Tutur Nongkojajar Kabupaten Pasuruan. BPS (2013) menyebutkan bahwa kecamatan yang memiliki sapi, sapi perah dan kerbau paling banyak adalah Kecamatan Tutur dengan jumlah populasi sebanyak 21.610 ekor. Selain itu, Kecamatan Tutur merupakan sentra ternak sapi perah yang memiliki kelompokkelompok peternak sapi perah dan tergabung dalam Koperasi Peternak Sapi Perah (KPSP) Setia Kawan Nongkojajar. Pemilihan kecamatan Tutur sebagai lokasi penelitian juga dikarenakan beberapa anggota KPSP Setia Kawan Nongkojajar telah menerapkan integrasi sapi perah dengan tanaman hortikultura.

Penelitian ini dilakukan secara survey. Metode penentuan sampel dilakukan secara purposive sampel menurut petunjuk Singarimbun dan Effendi (1989) dan Zuma (2006) yaitu sampel dipilih secara sengaja dengan maksud atau kriteria tertentu. Penelitian ini bermaksud mengkaji sistem integrasi ternak sapi perah dengan tanaman hortikultura, sehingga peternak sampel harus memenuhi kriteria utama penelitian, antara lain:

1. Peternak memiliki ternak sapi perah produktif minimal 2 (dua) ekor dan memiliki pengalaman beternak sapi perah minimal 1 (satu) tahun.

2. Peternak harus memiliki tanaman hortikultura, telah menggunakan pupuk organik sapi perah dan memiliki tanaman hijauan makanan ternak (HMT).

3. Peternak harus menjadi anggota kelompok peternak yang tergabung 
dalam Koperasi Peternak Sapi Perah (KPSP) Setia Kawan Nongkojajar.

4. Kriteria khusus lainnya yaitu peternak yang telah memiliki dan memanfaatkan reaktor biogas sehingga mampu menghasilkan sendiri pupuk organik bioslurry dari manure sapi perah yang dimanfaatkan untuk tanaman hortikultura.

Analisis data dilakukan secara deskriptif tabelaris-grafis-numeris yang membahas tentang bagaimana merangkum sekumpulan data dalam bentuk yang mudah dibaca dan cepat memberikan informasi yang disajikan dalam bentuk tabel, grafik, nilai pemusatan dan nilai penyebaran untuk mengambil kesimpulan penelitian.

\section{HASIL DAN PEMBAHASAN}

\section{Sistem integrasi sapi perah dengan tanaman hortikultura}

Sistem usahatani integrasi sapi perah dengan tanaman hortikultura di wilayah penelitian telah terbentuk secara alamiah yang bersifat independen antar satu komponen dengan komponen lainnya sebagai suatu sistem usahatani campuran (mix farming) yang cenderung diarahkan terutama untuk tambahan pendapatan rumahtangga, pendapatan dari satu komponen menjadi tambahan modal pada komponen lainnya dan meminimalkan risiko kegagalan pada salah satu usahatani. Sebagian petani peternak pola usahatani campuran (mix farming) sapi perah dengan tanaman hortikultura mulai menerapkan pola usahatani terintegrasi (integrated farming) sekalipun belum dilakukan secara penuh sejak adanya Program Biru (biogas rumahtangga) pada bulan Mei 2009.

Bersamaan dengan program biogas rumahtangga, pihak Hivos dan
Yayasan Rumah Energi (YRE) melakukan penyuluhan, pelatihan dan pendampingan penerapan sistem integrasi yang lebih terintegrasi antara komponen sapi perah dengan komponen tanaman hortikultura khususnya sayuran dan tanaman hijauan makanan ternak. Program Biru adalah inisiatif oleh Hivos salah satu LSM lingkungan dari Belanda dan dilaksanakan oleh Yayasan Rumah Energi (Biru, 2014 ${ }^{\mathrm{a}}$ ).

Hivos melalui program BIRU memberikan bantuan suntikan dana sebesar seperempat dari total biaya pembuatan reaktor biogas dan instalasi biogas rumahtangga bagi para peternak. Selebihnya dibiayai melalui pinjaman Koperasi Peternak Sapi Perah (KPSP) Setia Kawan Nongkojajar yang dikembalikan secara bertahap oleh peternak dengan menyisihkan hasil setoran susu sapi.

Program Biru selain menghasilkan biogas juga menghasilkan bioslurry yang digunakan sebagai pupuk organik pada tanaman hortikultura dan tanaman hijauan makanan ternak milik peternak sapi perah (Biru, 2014 ). Meskipun sistem usahatani terintegrasi (integrated farming system) belum dilakukan secara penuh, model sistem usahatani integrasi sapi perah dengan tanaman hortikultura telah diterapkan para peternak sapi perah khususnya peternak yang memiliki lahan usahatani tanaman hortikultura di wilayah penelitian.

Gambar 1 menunjukkan sistem integrasi sapi perah dengan tanaman hortikultura dengan sebagian komponen memiliki kaitan satu dengan lainnya baik secara langsung maupun tidak langsung. Program Biru dengan fasilitas digester biogas menjadi komponen katalisator terintegrasinya antar komponen dalam sistem integrasi sapi perah dengan tanaman hortikultura.

Pola tanam usahatani tanaman 
hortikultura dan tanaman hijauan makanan ternak di wilayah penelitian sebagian merupakan pola monokultura (monoculture) pada areal lahan berbeda dan sebagian merupakan pola pertanaman campuran atau polikultura (policulture) serta pola tanam rotasi penanaman jenis berbeda (rotational cropping) pada areal yang sama. Namun pola tanam responden penelitian umumnya melakukan pola tanam tum- pangsari tanaman hortikultura di lahan tanaman hijauan makanan ternak. Pola tanam tumpangsari merupakan suatu pertanaman dua jenis atau lebih tanaman cultivar pada bidang tanah dan waktu yang sama. Humphreys (1979) mengemukakan bahwa salah satu bentuk pola tanam tumpangsari yaitu pertanaman campuran antara tanaman pangan dengan tanaman hijauan makanan ternak (HMT).

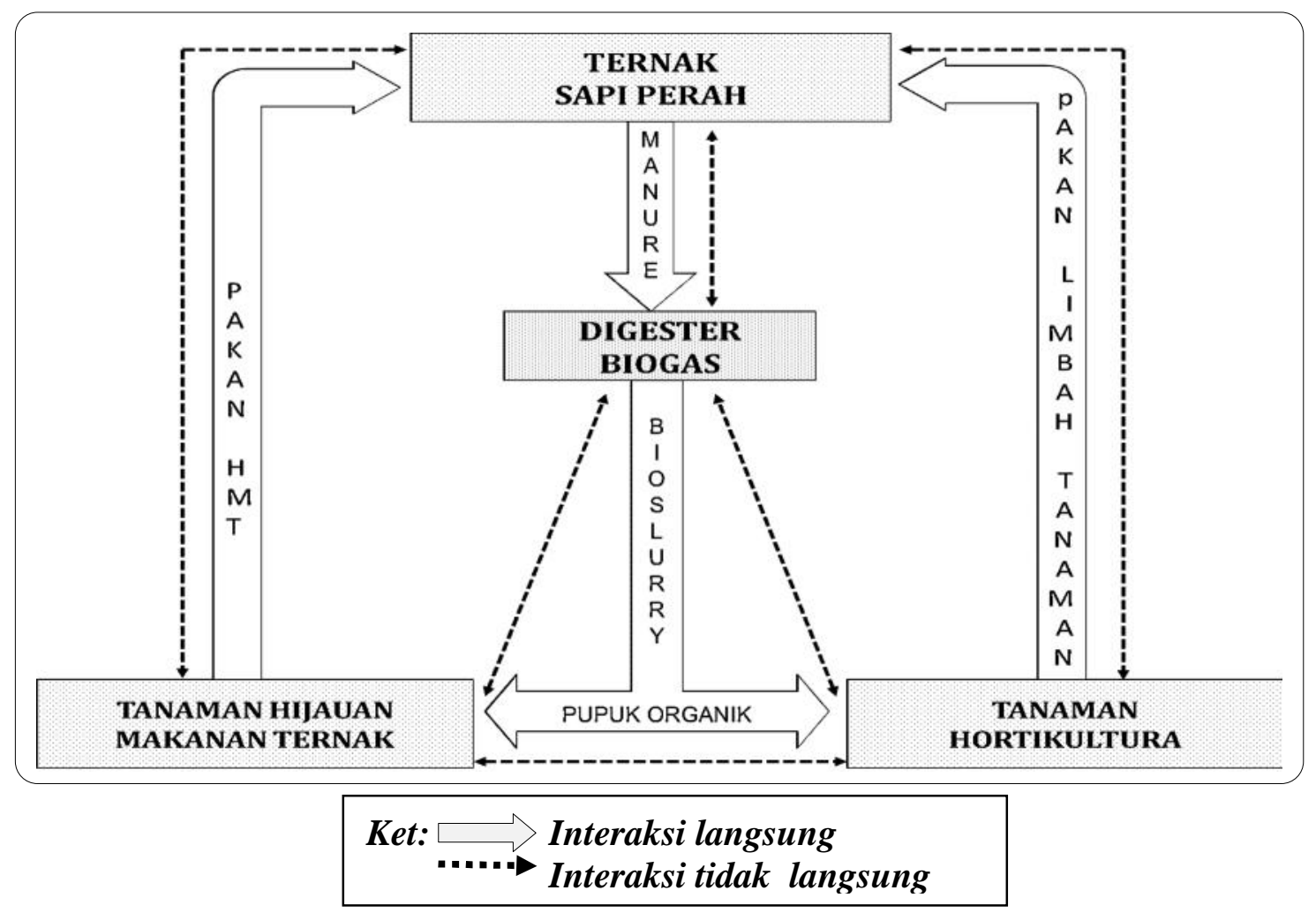

Gambar 1. Interaksi antar komponen sistem integrasi sapi perah dengan tanaman hortikultura (SISpTA)

Sistem integrasi menurut FAO (2001) terdiri dari komponen seperti tanaman dan ternak yang hidup berdampingan secara independen antara satu sama lainnya. Sistem integrasi sapi perah dengan tanaman hortikultura pada peternak responden terdiri dari empat komponen utama yaitu komponen usaha ternak sapi perah, komponen usahatani tanaman hortikultura, komponen tanaman hijauan makanan ternak (HMT) dan komponen digester biogas dan bioslurry. Interaksi kualitatif (perceived interactions) antar komponen di wilayah penelitian bersifat independen atau terpisah antar komponen maupun dependen atau saling pengaruh antara komponen yang satu dengan komponen lainnya.

Indikator interaksi kualitatif yang terjadi baik langsung maupun tidak langsung yaitu: (a) limbah dan pro- 
duk sampingan tanaman digunakan sebagai pakan ternak, (b) tanaman sela, penutup tanah atau pinggiran lahan yaitu tanaman hijauan makanan ternak (HMT) yang digunakan untuk pakan ternak sapi perah, (c) pupuk organik digunakan sebagai sumber hara tanaman hortikultura, (d) penjualan produk hasil ternak sebagai tambahan uang tunai membeli pupuk dan pestisida, (e) penjualan hasil tanaman hortikultura sebagai tambahan uang tunai pembelian input untuk usaha ternak sapi perah.

Produk sampingan (by-product) dari suatu komponen digunakan sebagai sumberdaya untuk komponen lainnya, seperti kotoran ternak digunakan untuk digester biogas menghasilkan bioslurry sebagai pupuk organik untuk tanaman hortikultura dan tanaman HMT dan limbah tanaman hortikultura digunakan untuk pakan ternak sapi perah. Kedua proses pemanfaatan kotoran ternak sapi perah ini menjadi sumber tambahan pandapatan ataupun penghematan biaya bahan bakar (biogas) dan biaya pupuk bagi petani peternak dan pendapatan ataupun hasil penghematan dapat digunakan untuk tambahan biaya produksi usaha ternak sapi perah maupun biaya produksi komponen lainnya. Proses integrasi meningkatkan pendapatan peternak dan mempertahankan kualitas sumberdaya pertanian peternakan serta sebagai bagian dari pengembangan pertanian peternakan berkelanjutan dan berwawasan lingkungan.

\section{Karakteristik sosial ekonomi responden}

Karakteristik sosial ekonomi peternak responden penelitian meliputi antara lain umur, pendidikan dan pengalaman beternak sapi perah. Gambar 2 menunjukkan karakteristik umur peternak responden.

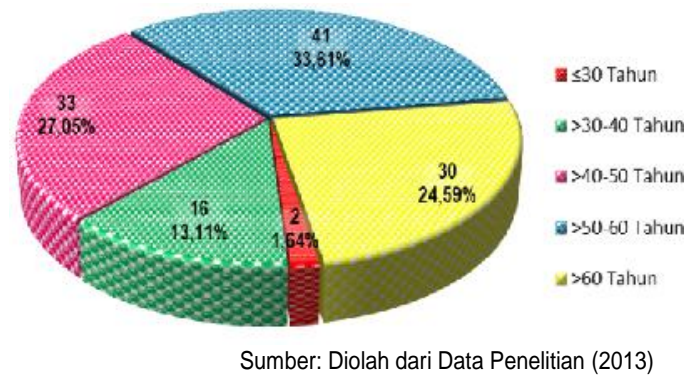

Gambar 2. Keadaan umur responden

\begin{abstract}
Gambar 2 menunjukkan sebagian besar peternak responden $(33,61 \%)$ berumur $>50-60$ tahun, berumur $>40-50$ tahun $(27,05 \%)$ dan berumur $>30-40$ tahun $(13,11 \%)$ yang seluruhnya tergolong umur dewasa produktif, sedangkan responden yang dewasa lanjut usia (lansia) >60 tahun masih cukup banyak yaitu sebanyak 30 peternak $(24,59 \%)$. Karakteristik umur responden ini menunjukkan para peternak sangat dewasa.
\end{abstract}

Gambar 3 menunjukkan tingkat pendidikan responden sebagian besar masih SD (50,82\%), SLTP $(15,57 \%)$ dan SLTA $(31,15 \%)$. Responden yang berpendidikan sarjana/pascasarjana hanya sebanyak 2 peternak $(1,64 \%)$ dan diploma sebanyak 1 peternak $(0,82 \%)$. Sebagian besar pendidikan responden yang rendah disebabkan sejak kecil mereka telah membantu orang tua dalam usahatani termasuk usaha beternak sapi perah. 


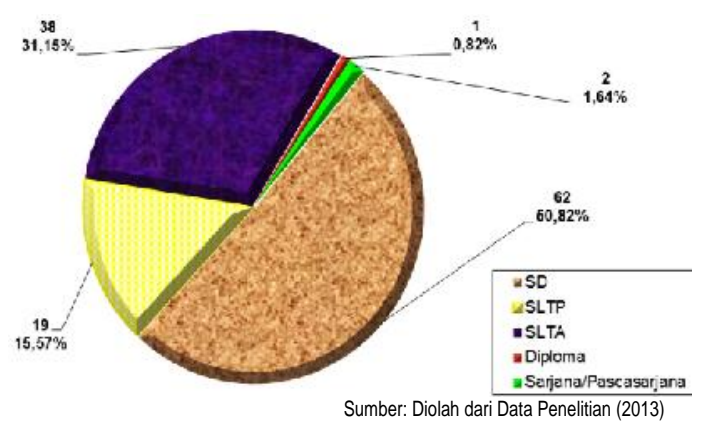

Gambar 3.Keadaan tingkat pendidikan responden

\begin{abstract}
Seorang peternak yang mempunyai pengalaman lebih lama berkecimpung mengurusi ternak sapi perah akan lebih cepat menangani ataupun lebih tanggap mengambil keputusan karena telah memiliki pengetahuan praktis dan pedoman dalam kegiatan usahanya. Pengetahuan praktis dan pedoman dalam menangani ternak sapi perah menyangkut feeding, breeding dan management lebih berat dibandingkan ternak lainnya. Semakin lama pengalaman beternak sapi perah, maka akan semakin kuat pengetahuan
\end{abstract}

\begin{abstract}
praktis peternak dalam menangani ternak sapi perah.

Gambar 4 menunjukkan bahwa $40,98 \%$ peternak responden sudah berpengalaman selama $>30-40$ tahun, bahkan seorang responden $(0,82 \%)$ berpengalaman lebih dari 50 tahun dan hanya 2 peternak $(1,64 \%)$ yang memiliki pengalaman kurang dari 10 tahun. Hal ini menunjukkan bahwa sebagian besar peternak sudah berpengalaman karena sejak remaja telah membantu orang tua beternak sapi perah sampai menjadi pemilik usaha sapi perah saat ini.
\end{abstract}

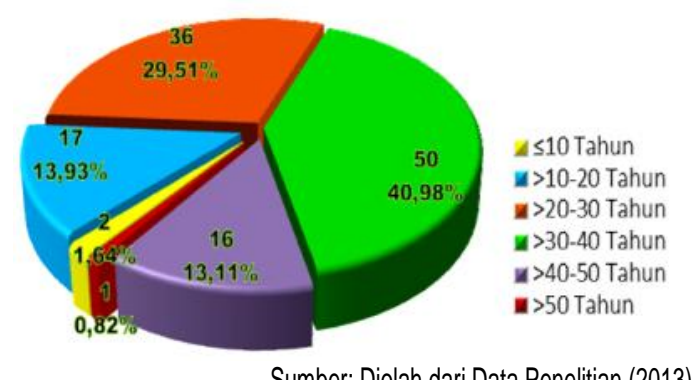

Gambar 4. Keadaan pengalaman beternak responden

\begin{abstract}
Sasaran utama implementasi program BIRU selama 5 tahun di Jawa Timur adalah peternak dengan kepemilikan ternak $>3$ ekor. Peternak dengan jumlah kepemilikan $\leq 19$ ekor belum diwajibkan izin usaha, sedangkan peternak sapi perah yang harus mengajukan izin usaha jika skala
\end{abstract}

$\begin{array}{lr}\text { usahanya >20 ekor sesuai } & \begin{array}{r}\text { Lampiran } \\ \text { Nomor: }\end{array} \\ \text { Kepmentan } & \text { Tentang } \\ \text { 404/kpts/OT.210/6/2002 } & \text { Pendaftaran } \\ \text { Pedoman Perizinan dan } & \begin{array}{l}\text { Penan } \\ \text { Usaha Peternakan. }\end{array} \text { Tabel 1 } \\ \text { menunjukkan karakteristik usaha ternak } \\ \text { sapi perah responden. }\end{array}$

usahanya >20 ekor sesuai Lampiran Kepmentan Nomor: 404/kpts/OT.210/6/2002 Tentang Usaha Peternakan. Tabel 1 menunjukkan karakteristik usaha ternak sapi perah responden. 
Tabel 1. Karakteristik usaha ternak sapi perah

\begin{tabular}{|c|c|c|c|}
\hline \multirow{2}{*}{$\frac{\text { No. }}{1 .}$} & \multicolumn{2}{|r|}{ Uraian } & Jumlah per responden \\
\hline & \multicolumn{2}{|c|}{ Anggota rumahtangga (orang) } & $4,09 \pm 1,36$ \\
\hline 2. & \multicolumn{2}{|c|}{ Kepemilikan lahan (Ha) } & $1,15 \pm 0,89$ \\
\hline 3. & \multicolumn{2}{|c|}{ Kapasitas kandang (ekor) } & $8,89 \pm 4,27$ \\
\hline \multicolumn{4}{|c|}{ 4. Kepemilikan sapi perah (ekor) } \\
\hline & \multirow[t]{2}{*}{ - Induk } & Laktasi & $4,03 \pm 2,74$ \\
\hline & & Kering & $0,83 \pm 1,04$ \\
\hline & - Dara & & $0,75 \pm 0,48$ \\
\hline & \multirow[t]{2}{*}{ - Pedet } & Jantan & $0,37 \pm 0,56$ \\
\hline & & Betina & $0,66 \pm 0,67$ \\
\hline & \multirow[t]{2}{*}{ - Pejantan } & Dewasa & $0,12 \pm 1,58$ \\
\hline & & Muda & $0,12 \pm 0,97$ \\
\hline & \multicolumn{2}{|c|}{ Jumlah kepemilikan sapi perah (ekor) } & $6,89 \pm 4,27$ \\
\hline & \multicolumn{2}{|c|}{ Jumlah Satuan Ternak (ST) } & $5,68 \pm 3,69$ \\
\hline & \multicolumn{2}{|c|}{ Jumlah IB setiap kebuntingan (S/C) (kali) } & $1,85 \pm 0,64$ \\
\hline & \multicolumn{2}{|c|}{ Tingkat kebuntingan pada IB pertama (CR) (\%) } & $74,11 \pm 16,65$ \\
\hline & \multirow{2}{*}{\multicolumn{2}{|c|}{$\begin{array}{l}\text { Jumlah produksi susu per hari (liter per hari) } \\
\text { Total Plate Count (TPC) }\end{array}$}} & $59,66 \pm 40,49$ \\
\hline & & & $952.616,98 \pm 41.200$ \\
\hline
\end{tabular}

Sumber: Diolah dari data penelitian (2013)

Tabel 1 menunjukkan bahwa usaha sapi perah dijalankan oleh peternak responden yang memiliki anggota rumahtangga rata-rata sebanyak $4,09 \pm 1,36$ orang yang sebagian di antara mereka sebagai tenaga kerja keluarga dengan curahan waktu kerja $1.861,23 \pm 1.152$ jam kerja setara pria per tahun. Pekerjaan yang dilakukan antara lain membantu memerah susu, menyetor susu, memberi pakan, membersihkan kandang, memandikan sapi, mencuci alat perah, merawat pedet, mengontrol birahi, memanggil inseminator, menolong kelahiran sapi, serta bertani tanaman hijauan makanan ternak dan tanaman hortikultura.

Peternak responden memiliki lahan sendiri seluas $1,15 \pm 0,89$ hektar untuk penanaman hijauan makanan ternak dan tanaman hortikultura. Pada umumnya peternak responden telah mampu membiayai dan membangun reaktor biogas, menggunakan biogas dan bioslurry sehingga menerapkan sistem integrasi sapi perah dengan tanaman. Kapasitas kandang milik peternak responden dapat menampung rata-rata sebanyak $8,89 \pm 4,27$ ekor sapi perah.

Jumlah kepemilikan ternak sapi perah sebanyak $6,89 \pm 4,27$ ekor atau $5,68 \pm 3,67$ ST per responden yang termasuk tinggi untuk ukuran usaha keluarga dibandingkan rata-rata kepemilikan sapi perah di Indonesia yang umumnya dalam skala kecil (hanya sebanyak 1-3 ekor). Kepemilikan ternak sapi perah responden didominasi oleh sapi induk laktasi dan kering. Jumlah kepemilikan sapi perah usaha rakyat pada umumnya sebanyak 1-3 ekor (Yusdja, 2005 dan Taslim, 2011). Namun beberapa penelitian menunjukkan bahwa kepemilikan sapi perah di Indonesia lebih dari 3 ekor seperti Astuti dkk (2010) yang melaporkan jumlah rata- 
rata sebesar 3,09 ekor dan Nugroho (2011) yang menemukan rata-rata kepemilikan sapi perah rakyat sebesar 6,36 ekor. Rata-rata kepemilikan sapi perah responden $\mathfrak{s} 0$ ekor yang berarti belum memenuhi kriteria wajib mengurus izin usaha.

Jumlah sapi laktasi rata-rata sebanyak 4,03 $\pm 2,74$ ekor $(58,50 \%)$, sedangkan sapi dara rata-rata sebanyak $0,75 \pm 0,48$ ekor $(10,94 \%)$ per responden yang disiapkan untuk menggantikan sapi induk jika telah memasuki umur tidak produktif. Jumlah sapi laktasi menentukan penerimaan usaha ternak sapi perah. Astuti dkk (2010) melaporkan rata-rata kepemilikan sapi laktasi sebanyak 2,3 ekor (63,70\%). Hartono (2005), Hartono (2011) dan Nugroho (2011) mengemukakan bahwa sebagian besar ternak sapi yang dipelihara adalah sapi induk. Jumlah sapi induk dan laktasi menjadi variabel yang memberikan kontribusi terbesar terhadap pendapatan usaha ternak sapi perah. Semakin besar jumlah sapi induk laktasi maka semakin banyak produksi, penerimaan dan keuntungan usaha sapi perah. Winarno (1985) menjelaskan bahwa sebaiknya persentase induk laktasi lebih dari $80 \%$ supaya dapat berpengaruh terhadap produksi susu dan keuntungan peternak.

Reproduksi sapi perah dilakukan

secara Inseminasi buatan (IB) yang secara teknis dilakukan petugas inseminator dari KPSP Setia Kawan. Triwulanningsih, dkk (2009) mengemukakan bahwa salah satu pengukuran efisiensi reproduksi pada sapi perah dapat dilakukan dengan menghitung conception rate (CR). Conception rate adalah angka tingkat kebuntingan dari perkawinan atau inseminasi buatan pertama. Di sisi lain jumlah perkawinan atau dilakukan IB per kebuntingan atau service per conception (S/C) merupakan suatu ukuran untuk mengetahui berapa kali sapi betina dikawinkan atau dilakukan IB sampai bunting dengan nilai normal berkisar antara 1,6-2,0.

Hasil penelitian menunjukkan bahwa service per conception (S/C) sebanyak 1,85 $\pm 0,64$ kali, sedangkan persentase atau tingkat kebuntingan pada perkawinan atau inseminasi buatan (IB) pertama atau conception rate (CR) sebanyak 74,11 $\pm 16,65 \%$. Hasil ini menunjukkan baik S/C maupun RC masih tergolong baik sebagaimana hasil penelitian Ihsan dan Wahjuningsih (2011) melaporkan S/C sebesar 1,37 dan RC sebesar 64-65\% tergolong sebagai penampilan reproduksi yang baik. Kepemilikan sapi perah yang semakin banyak menunjukkan semakin banyak pula jumlah sapi induk yang dikawinkan (IB). Setiap peternak responden mengawinkan sapi-sapi induk sebanyak $5,17 \pm 3,56$ kali setahun. Dengan demikian semakin banyak terjadinya kebuntingan sapi dan sapi yang melahirkan, maka semakin banyak sapi laktasi sehingga semakin banyak produksi susu.

Jumlah produksi susu di wilayah penelitian termasuk tinggi di Indonesia. Setiap peternak responden dengan jumlah sapi laktasi sebanyak 4,03 $\pm 2,74$ ekor menghasilkan susu sebanyak 59,66 \pm 40,49 liter per hari dengan rata-rata produksi susu sebanyak 14,12 $\pm 3,60$ liter/ekor per hari. Rataan produksi susu sekitar 10-12 liter per ekor per hari. Tingkat harga susu segar ditentukan melalui penentuan kualitasnya dimana standar kualitas susu segar dilihat dari kandungan bakteri (total plate count) yang berada pada kisaran antara 500.000 sampai 1.000.000 (Nugroho, 2010). Kualitas susu peternak responden rata-rata sebesar 952.616,98 \pm 41.200 per ml sehingga kandungan bakteri total plate count (TPC) tersebut masih tergolong baik. 
Hasil analisis biaya, penerimaan dan keuntungan usaha sapi perah pada Tabel 2 menunjukkan bahwa biaya ratarata per responden sebesar $\mathrm{Rp}$ 14.464.733 \pm 9.430 .683 per tahun dengan biaya terbesar yaitu biaya pakan dengan rata-rata per responden sebesar $\mathrm{Rp} 10.680 .244 \pm 6.838 .974$ per tahun atau $72,52 \%$ dari total biaya usaha sapi perah, sedangkan biaya paling kecil yaitu biaya $\mathrm{PBB} /$ retribusi/air/listrik /BBM sebesar Rp $347.084 \pm 201.037$ atau $2,13 \%$. Penerimaan yang diperoleh peternak rata-rata setiap per tahun sebesar Rp 23.357.321 \pm 3.938.351 sehingga setiap peternak responden mendapatkan keuntungan rata-rata Rp8.892.588 \pm 1.710.451 per tahun.

Tabel 2. Biaya, penerimaan dan keuntungan usaha sapi perah

\begin{tabular}{|c|c|c|c|c|}
\hline Uraian & \multicolumn{3}{|c|}{$\begin{array}{l}\text { Rata-rata per responden } \\
\text { (Rp/tahun) }\end{array}$} & \multirow[t]{2}{*}{$(\%)$} \\
\hline \multicolumn{4}{|l|}{ (I) Biaya : } & \\
\hline \multicolumn{5}{|l|}{ Biaya variabel (1) } \\
\hline - Biaya pakan & 10.680 .244 & \pm & 6.838 .974 & $(72,52)$ \\
\hline Biaya tenaga kerja & 2.534 .003 & \pm & 1.834 .886 & $(19,46)$ \\
\hline - Biaya IB,OVK, Keswan & 452.910 & \pm & 294.279 & $(3,12)$ \\
\hline \multicolumn{5}{|l|}{ Biaya tetap (2) } \\
\hline - Biaya penyusutan kandang/alat & 450.492 & \pm & 261.507 & $(2,77)$ \\
\hline - Biaya PBB/retribusi/lain-lain & 347.084 & \pm & 201.037 & $(2,13)$ \\
\hline Total biaya $(1+2)$ & 14.464 .733 & \pm & 9.430 .683 & $(100,00)$ \\
\hline Penerimaan : & 23.357 .321 & \pm & 3.938 .351 & \\
\hline (III) Keuntungan : ( II - I ) & 8.892 .588 & \pm & 1.710 .451 & \\
\hline
\end{tabular}

Sumber: Diolah dari data penelitian (2013)

Tabel 3 menunjukkan bahwa biaya tanaman hortikultura rata-rata per responden sebesar $\mathrm{Rp} 6.541 .632 \pm$ 4.660.611 per tahun dengan biaya terbesar yaitu biaya tenaga kerja dengan rata-rata per responden sebesar $\mathrm{R}$ $6.541 .632 \pm 3.286 .867$ per tahun atau $63,51 \%$ dari total biaya usahatani tanaman hortikultura.

Peternak sapi perah responden menanam tanaman hortikultura berkisar 1-3 jenis tanaman meliputi tanaman sayuran dan buah-buahan antara lain sayur wortel, sawi, kubis, tomat dan paprika, serta buah semangka, melon dan buah naga. Penerimaan tanaman hortikultura diperoleh melalui penjualan hasil tanaman hortikultura maupun dikonsumsi sendiri yaitu rata-rata setiap responden memperoleh sebesar $\mathrm{Rp}$ $10,030,225 \pm 7.752 .962$ dan memberikan keuntungan sebesar Rp $3,488,593 \pm 3.153 .018$.

Petani peternak responden telah menggunakan bioslurry sebagai pupuk organik pada tanaman hortikultura. Usahatani sapi perah menghasilkan bioslurry sebagaimana dijelaskan oleh Junus (2015) yaitu lumpur organik unit gas (LOUGB) merupakan lumpur kandang ternak (slurry) yang berasal dari kotoran ternak yang dimasukkan kedalam tangki pencerna unit gas bio untuk diproses menjadi gas bio dan lumpur organik unit gas bio yang dapat digunakan sebagai bahan bakar, sedangkan LOUGB yang sering disebut sludge dapat digunakan sebagai bahan pakan ternak/ikan dan pupuk tanaman.

Responden menggunakan pupuk organik pada tanaman hortikultura meskipun masih menambah dengan 
pupuk kimia sehingga terlihat biaya pupuk organik lebih besar dari biaya pupuk kimia. Akan tetapi sebenarnya biaya pupuk organik tidak dikeluarkan tunai, namun merupakan nilai ekonomi berdasarkan jumlah penggunaan menggantikan pupuk kimia, demikian juga biaya tenaga kerja sebagian besar adalah tenaga kerja keluarga yang tidak diupah secara tunai, sehingga keuntungannya lebih besar lagi.

Tabel 3. Biaya, penerimaan dan keuntungan usaha tanaman hortikultura

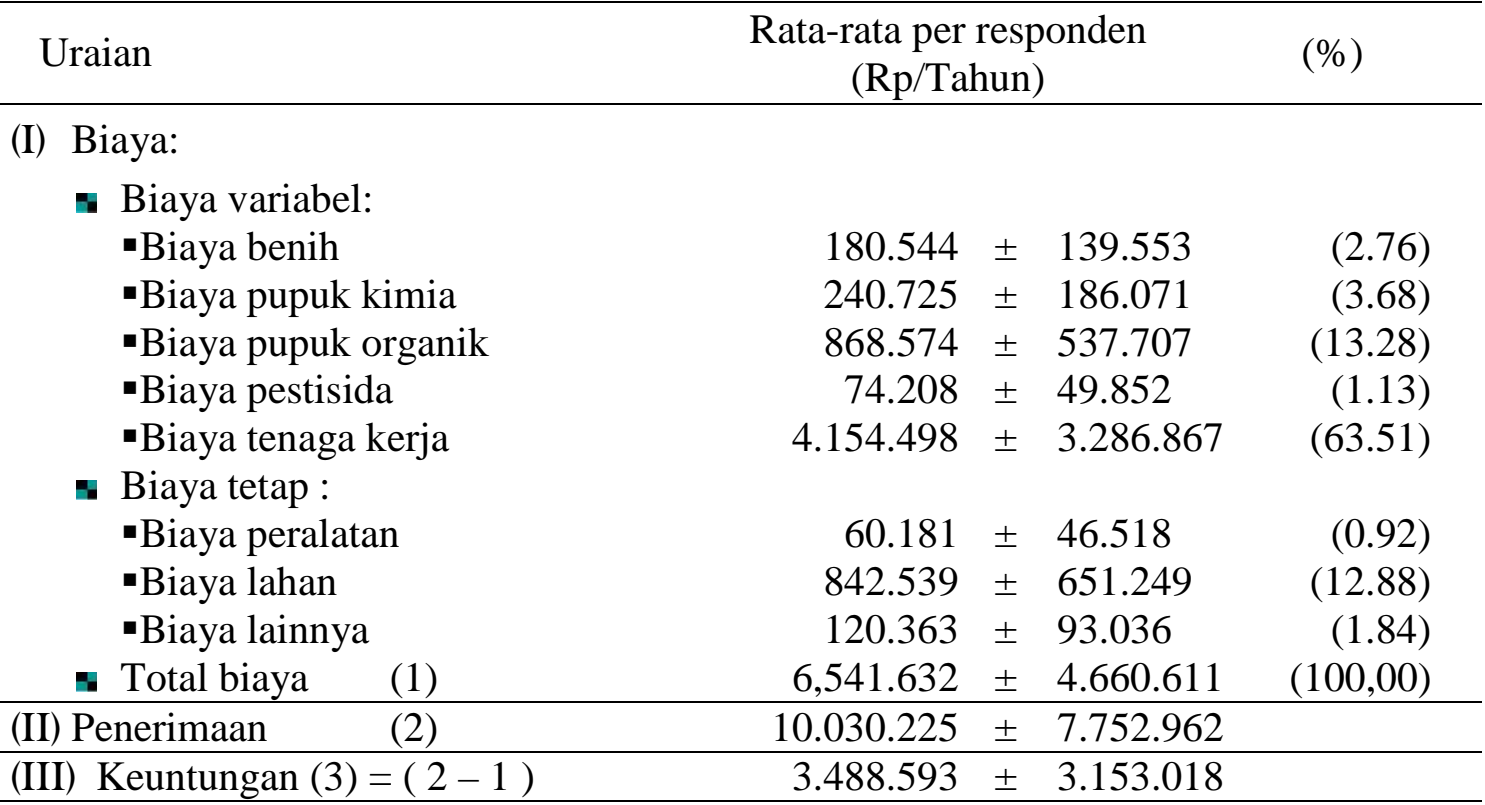

Sumber: Diolah dari data penelitian (2013)

Penerimaan setiap komponen dalam sistem integrasi sapi perah dengan tanaman hortikultura dapat dilihat pada Tabel 4.

Tabel 4. Penerimaan setiap komponen dalam usahatani sistem integrasi sapi perah dengan tanaman hortikultura (SISpTA)

\begin{tabular}{lcr}
\hline \multicolumn{1}{c}{ Penerimaan per Komponen } & $\begin{array}{c}\text { Rata-rata per responden } \\
(\mathrm{Rp} / \text { Tahun })\end{array}$ & $(\%)$ \\
\hline 1. Penerimaan usaha sapi perah & $23.357 .321,17 \pm 9.938 .351$ & $(46,54)$ \\
2. Penerimaan tanaman hortikultura & $10.030 .225,41 \pm 7.752 .962$ & $(19,99)$ \\
3. Penerimaan tanaman HMT & $12.380 .163,93 \pm 9.569 .370$ & $(24,67)$ \\
4. Penerimaan limbah tanaman & $1.595 .665,57 \pm 1.233 .386$ & $(3,18)$ \\
5. Penerimaan biogas & $1.087 .099,07 \pm 300.209$ & $(2,17)$ \\
6. Penerimaan bioslurry & $1.737 .147,54 \pm 1.075 .414$ & $(3,46)$ \\
\hline Total penerimaan & $50.187 .622,70 \pm 29.869 .692$ & $(100,00)$ \\
\hline
\end{tabular}

Sumber: Diolah dari data penelitian (2013)

Tabel 4 menunjukkan bahwa jika dilihat dari sisi penerimaan, terdapat tiga komponen utama dalam sistem integrasi sapi perah dengan tanaman yaitu usaha ternak sapi perah, usaha tanaman makanan ternak dan usahatani tanaman hortikultura. 
Penerimaan usaha sapi perah merupakan penerimaan terbesar $(46,54 \%)$ dan usahatani tanaman hijauan makanan ternak (HMT) menduduki penerimaan kedua terbesar $(24,67 \%)$ diikuti penerimaan usahatani tanaman hortikultura $(19,99 \%)$. Hasil memperlihatkan bahwa lahan tanah milik peternak sapi perah sebagian besar ditanami tanaman hijauan makanan ternak untuk memenuhi kebutuhan pakan sapi perah yang dipelihara dan hanya sebagian kecil ditanami tanaman hortikultura sebagai usahatani tambahan. Kontribusi penerimaan dari komponen produksi biogas dan pupuk organik dalam sistem integrasi masing-masing hanya $2,17 \%$ dan $3,46 \%$ yang berarti hanya kecil secara ekonomi, namun memberikan kontribusi cukup berarti secara pertanian ramah lingkungan dan berkelanjutan.

Penggunaan biogas dan bioslurry berdasarkan data yang diperoleh dari para peternak sapi perah dapat dilihat pada Tabel 5.

Tabel 5. Analisis deskriptif penggunaan biogas dan bioslurry

\begin{tabular}{|c|c|c|}
\hline No. & Uraian & Jumlah rata-rata setiap responden \\
\hline [1]. & Produksi biogas (m³/tahun) & $620,41 \pm 384,08$ \\
\hline & Produksi biogas setara LPG (kg/tahun) & $285,39 \pm 176,68$ \\
\hline & Penggunaan biogas setara LPG (kg/tahun) & $100,80 \pm 27,84$ \\
\hline & Biogas tak terpakai (kg/tahun) & $184,59 \pm 174,32$ \\
\hline & $\begin{array}{l}\text { Nilai biogas terpakai setara LPG non subsidi } \\
\text { (Rp/tahun) }\end{array}$ & $3.077 .915,24 \pm 1.905 .441,59$ \\
\hline [6]. & Nilai biogas terpakai setara LPG subsidi (Rp/tahun) & $1.331 .813,11 \pm 824.484,08$ \\
\hline & Nilai biogas terpakai (Rp/tahun) & $1.087 .099,07 \pm 300.209,15$ \\
\hline & Biaya produksi biogas (Rp/tahun) & $336.885,25 \pm 21.371,64$ \\
\hline & $\begin{array}{l}\text { Nilai ekonomi (keuntungan) biogas terpakai } \\
(\text { Rp/tahun) }=[7]-[8]\end{array}$ & $750.213,82 \pm 286.859,55$ \\
\hline [10] & Jumlah penggunaan LPG bersubsidi (kg/tahun) & $69,89 \pm 18,33$ \\
\hline [11] & Jumlah biaya pembelian LPG bersubsidi (Rp/tahun) & $326.131,15 \pm 85.522,89$ \\
\hline [12] & Produksi bioslurry (kg/tahun) & $17.371,48 \pm 10.754,14$ \\
\hline [13] & Nilai jual bioslurry (Rp/tahun) & $8.685 .737,70 \pm 5.377 .070,07$ \\
\hline [14] & Biaya produksi bioslurry & $6.948 .590,16 \pm 4.301 .656,05$ \\
\hline$[15]$ & $\begin{array}{l}\text { Nilai ekonomi (keuntungan) bioslurry terpakai } \\
=[13]-[14]\end{array}$ & $1.737 .147,54 \pm 1.075 .414,01$ \\
\hline
\end{tabular}

Sumber: Diolah dari data penelitian (2013)

Tabel 5 menunjukkan bahwa produksi biogas per tahun rata-rata sebesar 285,39 $\pm 176,68 \mathrm{~kg}$ setara LPG setiap tahun, namun yang terpakai oleh keluarga hanya sebesar 100,80 $\pm 27,84$ $\mathrm{kg}$ per tahun sehingga biogas yang terbuang sia-sia ke udara masih sebesar $184,59 \pm 174,32 \mathrm{~kg}$ per tahun. Hal ini terjadi karena rumahtangga masih menggunakan LPG selain biogas. Dalam rangka meningkatkan penggunaan biogas oleh para peternak pemilik reaktor biogas, maka diperlukan kebijakan pemerintah berupa insentif konversi subsidi LPG ke subsidi biogas.

Tabel 5 menunjukkan bahwa setiap rumahtangga peternak memproduksi bioslurry sebesar 
$17.371,48 \pm 10.754,14 \mathrm{~kg}$ per tahun sebagai substitusi pupuk kimia yang digunakan pada tanaman hijauan makanan ternak dan tanaman hortikultura. Nilai penggunaan bioslurry sekitar Rp 8.685.737,70 \pm 5.377.070,07 per tahun per rumah tangga yang memberikan nilai ekonomi (keuntungan) kepada peternak sebesar Rp 1.737.147,54 $\pm 1.075 .414,01$ per tahun per rumahtangga. Hasil ini nampaknya hanya memberikan kontribusi yang relatif kecil, tetapi memberikan keuntungan lingkungan dan kesehatan yakni memberikan keseimbangan zat hara tanah. Meskipun pemanfaatan pupuk organik sebagai hasil ikutan usaha sapi perah masih relatif kecil, namun sudah dapat mengurangi penggunaaan pupuk kimia yang makin langka dan mahal di pasar, serta mengurangi dampak kurang baik terhadap lingkungan dan bagi kesehatan kosumen pangan.

\section{KESIMPULAN DAN SARAN}

\section{Kesimpulan}

Sistem usahatani terintegrasi (integrated farming system) sekalipun belum dilakukan secara penuh, namun model sistem usahatani integrasi sapi perah dengan tanaman hortikultura telah diterapkan para peternak sapi perah, khususnya peternak yang berusahatani tanaman hortikultura. Fasilitas konstruksi digester biogas menjadi komponen katalisator terintegrasinya antar komponen dalam sistem integrasi sapi perah dengan tanaman hortikultura.

\section{Saran}

Pemerintah perlu memberi
prioritas pengembangan sistem usahatani terintegrasi ternak sapi perah dengan tanaman untuk mengefektifkan sistem usahatani yang berkelanjutan dan ramah lingkungan. Dalam rangka meningkatkan penggunaan biogas oleh para peternak pemilik reaktor biogas, maka pemerintah perlu memberikan insentif konversi subsidi LPG ke subsidi biogas. Selain itu, penelitian ini bersifat global sehingga perlu dilanjutkan dengan penelitian detail setiap komponen sistem integrasi ternak sapi perah dengan tanaman, baik tanaman hortikultura, florikultura, perkebunan maupun tanaman hijauan makanan ternak serta komponen biogas dan bioslurry.

\section{DAFTAR PUSTAKA}

Adiarto. 2012. Beternak sapi perah ramah lingkungan. Citra Aji Pramana. Yogyakarta.

Astuti, M., R. Widiati dan Y. Y. Suranindyah. 2010. Efisiensi produksi usaha sapi perah rakyat (Studi kasus pada peternak anggota Koperasi Usaha Peternakan dan Pemerahan Sapi Perah Kaliurang, Sleman, Yogyakarta). Buletin Peternakan 34(1): 64-69.

Biru. 2014 ${ }^{\mathrm{a}}$ BIRU digester. http://www.biru.or.id/en/index.p hp/digester/ Diakses tanggal 12 Mei 2015.

Biru. 2014 ${ }^{\mathrm{b}}$ Bio-slurry extension. http://www.biru.or.id/en/index.p $\mathrm{hp} /$ bio-slurry/. Diakses tanggal 12 Mei 2015.

BPS. 2013. Laporan hasil sensus pertanian 2013 (Pencacahan Lengkap). Badan Pusat Statistik Republik Indonesia. Jakarta.

Chuzaemi, S. 2009. Peternakan terpadu atasi pemanasan global. http://www.Mustang89. com/literatur/80-isu-peternakanumum/219-peternakan-terpaduatasi-pemanasan-global-?format =pdf. Diakses tanggal 3 Desember 2011.

FAO. 2001. Mixed crop-livestock 
farming: A review of traditional technologies based on literature and field experience. Animal Production and Health Papers 152. Rome.

FAO. 2010. Sete Lagaos "Consensus" on Integrated Crop-LivestockTree Systems form Sustainable Development (IC-LSD). An international consultation on integrated crop-livestock systems for development. The way forward for sustainable production intensification. Integrated Crop Management Vol.13-2010. Rome.

Hartono, B. 2005. Struktur pendapatan peternak sapi rakyat: Studi kasus Desa Pandesari Kecamatan Pujon, Kabupaten Malang. J. Indon. Trop. Anim. Agric 30(3):151-156.

Hartono, B. 2011. Upaya peningkatan ekonomi rumahtangga peternak sapi perah. UB Press. Malang.

Humphreys, L. R. 1979. Tropical pasture and fodder crops. ITAS, Longman Group Ltd., London.

Ihsan, M. N dan Wahjuningsih, S. 2011. Penampilan reproduksi sapi potong di Kabupaten Bojonegoro. J. Ternak Tropika 12(2):76-80.

Junus, M. 2015. Pengaruh cairan lumpur organik unit gas bio terhadap persentase kandungan bahan organik dan protein kasar padatan lumpur organik unit gas bio. Jurnal Ilmu-Ilmu Peternakan 25(1):35-41.

Nugroho, B. A. 2010. Pasar susu dunia dan posisi Indonesia. Jurnal Ilmu-ilmu Peternakan 20(1): 6576.

Nugroho, E. 2011. Status sosial ekonomi peternak sapi perah di Kecamatan Poncokusumo Kabupaten Malang J. Ternak Tropika 12(2):47-51.
Singarimbun, M dan Effendi, S. 1989. Metode penelitian survai. LP3ES. Jakarta.

Sujana, Tj. D. 2009. Sistem integrasi ternak-tanaman pangan menuju swasembada daging 2014. Makalah keynote speech dalam International seminar on Animal Industry 2009 di IPB International Convention Center (IICC). http://www.ipb.ac.id/ index.php/admin/portal/searchR esult?cx=01093 8425809678197 807\%3Axwaofkdjmnc\&cof $=$ FO $\underline{\text { RID\%3A10\&ie }=U T F 8 \& q=\text { Siste }}$ m+Integrasi+Ternak-Tanaman + Pangan+Menuju+Swasembada + Daging $+2014 \& x=20 \& y=8$. Diakses tanggal 31 Januari 2012. Taslim. 2011. Pengaruh faktor produksi susu usaha ternak sapi perah melalui pendekatan analisis jalur di Jawa Barat. Diponegoro Journal of Economics 2(1):1-8.

Triwulanningsih, E., T. Susilawati dan Kustono. 2009. Reproduksi dan inovasi teknologi reproduksi. Dalam K. A. Santosa, K. Diwyanto dan $\mathrm{T}$. Toharmat (Penyunting). Profil usaha peternakan sapi perah di Indonesia. Pusat Penelitian dan Pengembangan Peternakan. Bogor.

Winarno. 1985. Analisa manajemen dan pemasaran susu usaha peternakan sapi perah rakyat dan perusahaan sapi perah di Kotamadya Yogyakarta. Tesis. Fakultas Peternakan. Universitas Gadjah Mada. Yogyakarta.

Yusdja, Y. 2005. Kebijakan ekonomi agribisnis sapi perah di Indonesia. Analisis Kebijakan Pertanian 3(3):257-268.

Zuma, K. 2006. Public expenditure tracking surveys sampling. Human Sciences Research Council. Pretoria. 